University of Nebraska - Lincoln

DigitalCommons@University of Nebraska - Lincoln

3-2009

\title{
Why We Have Field Stations: Reflections on the Cultivation of Biologists
}

John J. Janovy Jr.

University of Nebraska - Lincoln, jjanovy1@unl.edu

Krista M. Major

University of Nebraska - Lincoln, kmmajor@aol.com

Follow this and additional works at: https://digitalcommons.unl.edu/bioscijanovy

Part of the Parasitology Commons

Janovy, John J. Jr. and Major, Krista M., "Why We Have Field Stations: Reflections on the Cultivation of Biologists" (2009). John Janovy Publications. 55.

https://digitalcommons.unl.edu/bioscijanovy/55

This Article is brought to you for free and open access by the Papers in the Biological Sciences at DigitalCommons@University of Nebraska - Lincoln. It has been accepted for inclusion in John Janovy Publications by an authorized administrator of DigitalCommons@University of Nebraska - Lincoln. 
Editor's note: This article serves to launch a planned series of peer-reviewed articles in BioScience about biological field stations and marine laboratories. Future articles in the series will address specific aspects of the operations and contributions of these venerable institutions.

\title{
Why We Have Field Stations: Reflections on the Cultivation of Biologists
}

\author{
JOHN JANOVY JR. AND KRISTA M. MAJOR
}

\begin{abstract}
For a resident of the state of Nebraska, the Cedar Point Biological Station (CPBS), located in scenic limestone bluffs below Kingsley Dam, an earthfilled artificial mountain that impounds a lake 35 kilometers long and 5 kilometers wide, is a bargain in American higher education. In three weeks a student can earn four credits of upper-division coursework, get original research experience, and, most importantly-especially in an educational milieu increasingly characterized by electronic content and electronic course management-get his or her hands on some live wild plants and animals in an appropriate ecological context. This encounter with nature is typically the first for our high-performer premed students on academic scholarships, who regularly attend CPBS after their junior year. The life-long impact of such experience includes lost naïveté with respect to living systems, appreciation of the relationship between environment and health, and, for some, a career choice leading to professional science.
\end{abstract}

Keywords: field stations, problem solving, undergraduate education, nature of science, career choices

"Wagine yourself, fifteen years from now, telling a patient to 'take
two aspirins and call me in the morning,' but when he does
call the next morning, after taking two bottles of
aspirin washed down with a pint of vodka, it's from Chat-
tanooga, and he has absolutely no idea how he got there."
When an audience of premedical students hears that story
in my class at the Cedar Point Biological Station (CPBS),
there are smiles all around. The message is fairly clear: what
seems so easy to accomplish when you command it is in fact
a rather uncontrollable set of events when you're dealing
with real organisms. Suddenly a city campus lab's poverty-
poverty imposed by a lack of resources and the need for
lab exercises that "work" in two and a half hours-becomes
obvious. As these students struggle with their microscopes,
now in a situation where they really need to be able to use one,
a teacher with field experience tries to explain the matter of
context: a freshwater pond, a braided prairie river, seasonal-
ity, the prey-predator relationships upon which their worm
depends, and, in the case of parasites, avenues for and
constraints on transmission, all in terms of this parable.
The future doctor's advice to take two aspirins and call in the morning is simplistic, the rough equivalent of a life cycle or food-web diagram in a textbook; the world into which these instructions, and thus the expectations, are delivered is exceedingly complex, with multiple sources of variation. It rarely takes more than a single encounter between students, a problem to be solved, and wild animals (even though these animals usually are microscopic) before these premeds understand what they have started to learn at a field program.

"At least the guy called," someone usually says, giving nature a little bit of credit. Again there are smiles all around. But the next time we go to the field for an exercise, or the next time they collect insects for their own class projects, there is a noticeable maturity, a sense of the relationship between a hypothesis, the data necessary to test it, and the resources involved in gathering and analyzing those data. This intellectual maturation happens very quickly. At CPBS, is it not unusual for 20 people to spend 14 hours on a single day's work before each of them stands in front of the class and tells what he or she has learned that day. Two hundred eighty 


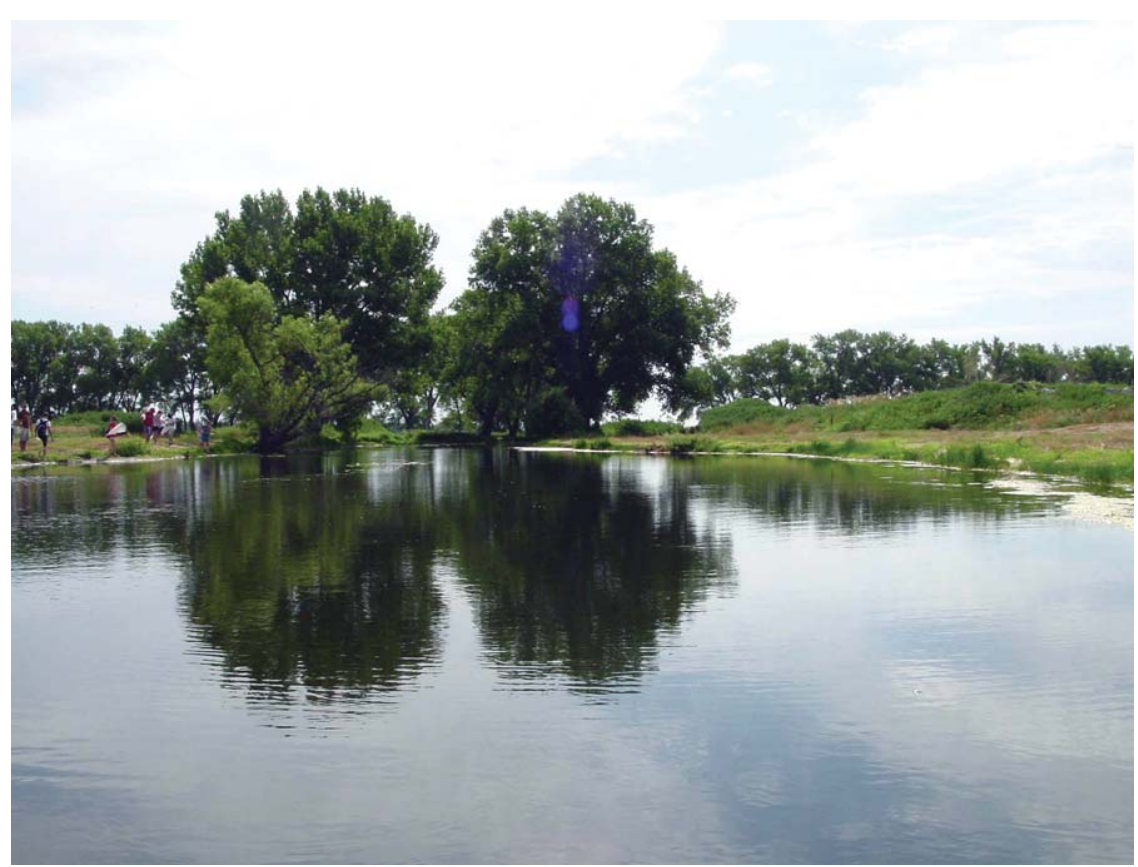

Dunwoody Pond in western Nebraska. Although it looks like a typical high plains artificial wetland, the landowners' willingness to let university students use this site for class projects and even thesis research has made it the equivalent of a classroom and laboratory building fully supplied with hundreds of species in their proper ecological context. No amount of money could replicate this facility, or the experience it provides, in a three-hour lab period on city campus. Photograph: John Janovy Jr.

person-hours is a full month of work compressed into a single day, into a single mini-investigation. By Wednesday of their first week, they've begun to understand the nature of original intellectual endeavor and the difference between the labor required to get a grade in some course versus the labor required to learn something from the study of nature.

If a field experience can offer anything that transcends subject matter, it is this lesson in the amount of work, as well as the character of that work, associated with the acquisition of knowledge, insight, and wisdom. This lesson is one of a particular kind of engagement with the subject matter, and in biology at least, it is one that our students are increasingly deprived of by the information age. For example, not long ago one of the authors of this article was standing by a pond watching 20 people collect aquatic invertebrates when a student came up to comment on the earlier introduction to the exercise for the morning.

"That modeling discussion didn't just go over my head," she said. "It sailed way over." She demonstrated the trajectory with a swoop of her hand.

On this particular day we were attempting to assemble the life cycle of a frog lung fluke to demonstrate how research into a set of discrete ontological events might be done in the field, and to quantify some of these events so that they could be matched to a computer simulation. The simulation itself was a device for studying the evolution of life cycles, and before we'd gone out to a local ranch, we'd explained the rationale behind the design, the sequence of commands in the code itself, and the evolutionary questions the model was supposed to address. This student was a member of the university honors program; she obviously was highly intelligent and capable, but just as obviously she was out of her frame of reference. So we returned to the earlier discussion and to the things we needed to quantify, starting with the arena in which all of the life-cycle participantssnails, a dozen species of aquatic arthropods, and frogs - encountered one another.

The first question was reasonably simple: "How would you measure the size of this pond?"

"I'd call up Google Earth," she responded instantly, "and get the coordinates, then use those to calculate area." It was not a large pond; she probably could have thrown a handful of duckweed across it to splat one of her classmates. She didn't mention the geometry involved in the use of Google Earth latitudes and longitudes; the pond's surface was not spread out in a regular polygon, and the depth was not uniform.

"Suppose we'd brought along a hundredfoot tape from the station and had it back in the van?" There was some silence. The idea of a hundred-foot tape was not a part of her intellectual equipment, through no fault of her own. Instead, modern higher education's reliance on information technologyindeed, its borderline worship of technology such as the campuswide wireless access touted as a student attraction to my school, course management software, and constant cell phone chatter-had shaped her sense of how to solve a problem: call up something on the Web, that is, consult an authority, although admittedly the authority in this case was a simple source of numbers, namely, latitudes and longitudes to the hundredth of a degree.

This conversation about problem solving continued throughout the day as we returned to the lab, did the infection experiments, and demonstrated the results to one another. Later that evening, the same student reflected on what we'd accomplished by addressing a historical matter, the disappearance of evidence into cyberspace. Hard drives, flash drives, and CDs with finite shelf lives, along with their primitive ancestors the floppy discs, are all ephemeral compared with a manuscript on acid-free paper marked up with a good pencil.

"We're losing the opportunity to see how people worked, how they solved problems in science, art, literature, music," she said.

Then the discussion turned to what you could learn about creativity from studying the receipts from cheap motels and the bar napkins upon which were penciled original country 
song lyrics, all on display at Nashville's Country Music Hall of Fame, or from the approximately 1400 surviving Rembrandt drawings, also done on about anything within arm's reach of the artist, whether a leather-bound book or the back of a funeral notice. None of these young people had ever seen an original set of field notes or laboratory notebooks; their first encounter with a data sheet-with even the idea of a data sheet (an organized record of observations) — was with the one they'd made themselves on our first day of class, as they stood at the classroom computer, entering lengths and sexes of damselfly larvae, along with the numbers of protistan parasites of several different species in and on each larva. Somehow, doing the work necessary to test their preconceived notions about how infective agents distribute themselves throughout the environment primed these students for a broader reflection on the nature of intellectual endeavor.

Because they'd participated in the exploration, from guiding paradigm to interpretation of statistical analysis, and because there was absolutely nothing in a textbook or on the Internet that was di-

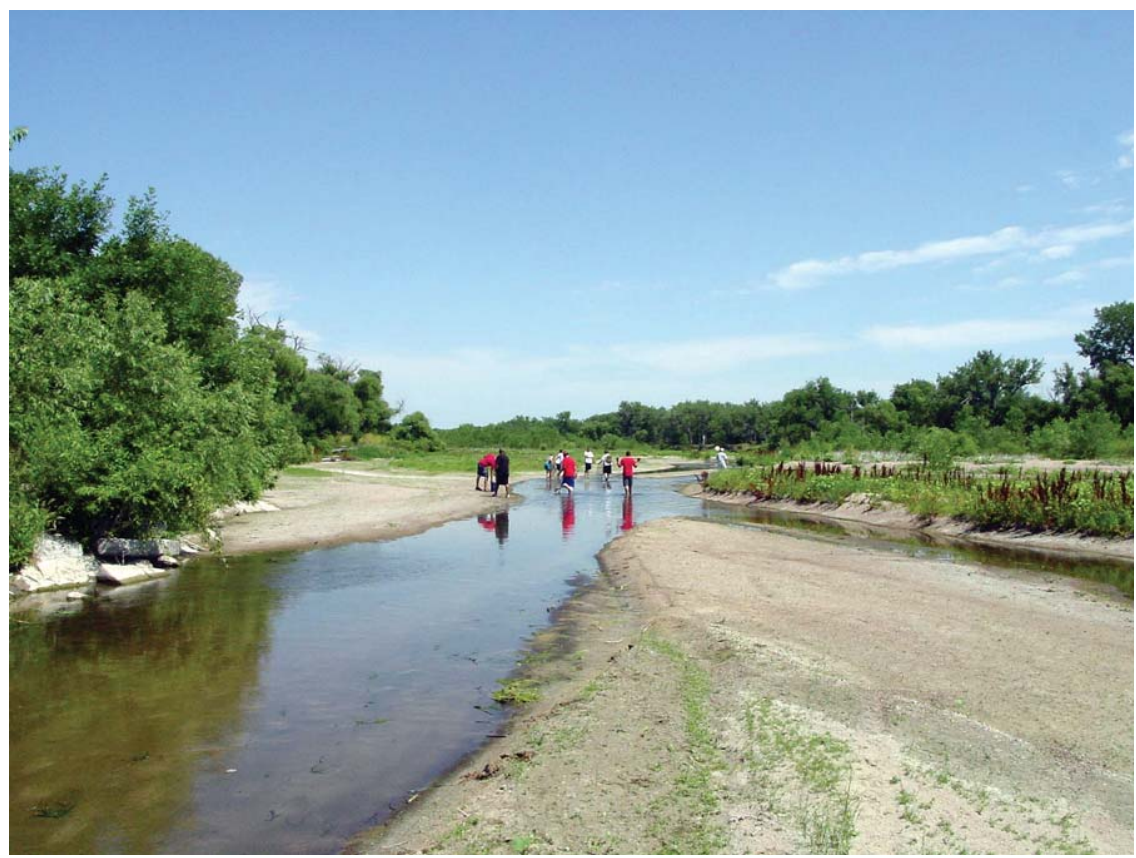

South Platte River near Roscoe, Nebraska. Within two hours of starting their three-week class, students from the nearby Cedar Point Biological Stationmostly prehealth professions majors - are completely absorbed in a search for materials to support individual projects that pique their interests. This quick transformation into beginning researchers is typical of a biological field station experience. Photograph: John Janovy Jr. rectly related to their day's work, whatever they'd done in the previous 10 hours seemed original. None of them knew that various classes in previous years had done this same kind of combined field and lab exercise at least a dozen times before, or that the taxonomy of our protists had been explored in great depth by a former graduate student over the course of the past decade. So nobody asked whether or when that particular exercise had been done before, or whether we'd come up with the right answer; everybody wanted to know the final results of our day's work, and if our data supported a concept, namely, that parasite populations tend to be aggregated, with most host individuals either uninfected or lightly so but with a few very heavily infected. Suddenly a spreadsheet on the screen became intellectual property, owned because of its origin, tangible evidence of accomplishment, not unlike a sketch drawn in a notebook or a few lines of lyrics scrawled on a bar napkin in a fit of creativity. The generalization was easy: when you are in possession of an idea and carry out the physical labor necessary to explore that idea, then you also develop a sense of ownership-in this case, ownership of the results.

In essence, therefore, a class exercise in the field is a highly simplified, but nevertheless valid, model for research, differing from a city campus lab exercise mainly in the logistical burden, the compression of time, and the predictable or desired outcome. Our students at the field station are doing what we faculty members do in order to stay in shape intellectuallyin other words, to retain our perspective, our enthusiasm, our mental capacities, and our mature response to review. The reason for attending a field program in biology thus becomes obvious: a field station is the one place in today's higher education establishment where you can actually play the role of a productive scholar, abbreviated, perhaps, but nevertheless real, in some exceedingly important ways, all the while surrounded by natural beauty. The ontogeny of a scientist throughout history often has followed this same course: looking at a natural environment in a new and unbiased manner, letting curiosity and personal interest drive the selection of problems to explore in depth, framing the appropriate questions and the testable predictions, struggling with the logistical demands and time management of research, then bringing one's efforts to closure with a paper and presentation. The fact that this encounter with wild organisms so often eventually leads to the lab or back to the Internet on a search for nucleotide sequences does not dilute the importance of those first experiences. The best questions often come from the organisms themselves, a fundamental lesson most easily learned in a field program.

\section{Formative career influences}

This track from young naturalist to professional scientist is typical of many famous biologists, regardless of their ultimate specialty areas. According to Robert Koch's brother, "While we gave our time to youthful games, Robert devoted his to nature study"; Alexander Fleming "spent many hours exploring the fields, woods, and streams"; and even James Watson ad- 
mitted that "my boyhood interest in bird-watching had matured into a serious desire to learn genetics" (Berger 1968). In his youth, Thomas Hunt Morgan, cofounder (with William Bateson) of modern genetics and winner of the 1933 Nobel Prize, spent endless hours in the woods, developing a breadth of interest that eventually led to publications involving at least 50 different animal species (Allen 1978). And, of course, E. O. Wilson has let us see his developing interest in biology through his own writings (Wilson 1994); his career may be an ideal model for the nation's development of scientific resources in general. Granted, we cannot all be E. O. Wilson, but, ideally, productive scientists should not only emerge from the student body but also mature intellectually past the stage of generating routine peer-reviewed papers and into a reflective period during which larger monographs that transcend specific disciplines are produced, such as Wilson's Consilience: The Unity of Knowledge (Knopf, 1998) and The Creation: An Appeal to Save Life on Earth (W. W. Norton, 2006).

Our own experiences with faculty colleagues may not be typical of the profession of biologist at an American university, especially a fairly large one, but it is nevertheless informative relative to the growth of scientific expertise. All of these colleagues are practicing scientists, and virtually all of them publish at some regular rate. They search for resources to support their research, they do classroom duty when assigned, and most of their day-to-day communication about science is with like-minded colleagues, often halfway around the world. Virtually all of them, however, have forgotten what it was like to be a beginning student, to deal with that first experiment that didn't "work," to identify a strange plant or animal using taxonomic literature, to dissect something other than a frog or rat, or to be stymied in their attempt to domesticate some microscopic creature that is as uncooperative as it is beautiful. And speaking of beauty, the vast majority of them seem ashamed of the word, at least in public, unless it is applied to experimental design. But field station experiences, especially when working side by side with students, tend to jog faculty members' memories, reminding them of their own days as beginning biologists.

This link between the conditions under which biologists begin their professional lives and the activities needed to continue them must be strong if our nation is to maintain its scientific competitiveness. As might be expected, the wellknown relationship between hands-on work, attitude, learning, and confidence, admitted by anyone from a plumber's apprentice to an NFL rookie quarterback, has been studied formally and extensively by pedagogical researchers, especially those whose interests are in science (e.g., Falk 1983, Freedman 1997, Bell et al. 2003, Knox et al. 2003, Markowitz 2004). A relatively surprising element of this research, and one that is often belittled by academics in the sciences, is that attitude matters, and this claim is well supported by studies done over the past 50 years (Ornstein 2006, Zoldosova and Prokop 2006; also see citations in Freedman 1997). To quote Freedman's (1997) summary of this body of work, "liking science was correlated with achievement in science." Although Freedman's particu- lar study involved ninth-grade physical science classes with and without laboratories, the underlying idea that physical labor associated with mental labor (i.e., practical or applied work combined with conceptual or theoretical work in a discipline) strengthens interest, attitude, and performance can easily be generalized. After all, professional biologists, especially those who perform well and often, are vitally interested in their subject and, whether they admit it in faculty meetings or not, love their work (attitude). After watching literally hundreds of undergraduates, those of us who teach field courses routinely can claim that a biological field station provides one of the most effective environments for permanently altering a college student's attitude, interest, and performance in biology. Faculty members should know that from their own personal histories.

The value of "outdoor" learning (as opposed to physics labs in school), with particular focus on student attitudes toward science, also has been demonstrated repeatedly by research over the past decades. Formal studies show us exactly what happens in a field experience, although, as is the case with much pedagogical research, the subjects are middle-school students. For example, Orion and Hofstein (1994) began with the claim that "outdoors" is a neglected learning environment compared with the classroom and laboratory, and proceeded to show that two factors have a major impact on the instructional quality of an outdoors experience: (1) some focused preparation, and (2) the timing of the trip. Orion and Hofstein (1994) concluded that, in contrast to what often happens with university-level field programs, a field experience "should be placed early in the concrete part of the learning activity, and should be focused mainly on concrete interaction between the students and the environment." The question is whether those college students not necessarily "interested in ecology," as indicated by their chosen majorfor example, premeds - are similarly affected, and I contend the answer is yes, although that contention arises mainly from personal experience. But at the university level, the timing of field programs is, we believe, a major factor in the programs' success. If Orion and Hofstein (1994) are correct, then we should be getting those premeds out into the field early and often, certainly no later than the summer between sophomore and junior years, regardless of what professional advisers are telling them about shadowing physicians and doing internships at medical schools to pad their résumés.

One of the relatively recent developments in science education is a focus on the nature of science, in addition to the content and practice of science (Bell et al. 2003). If the culture wars being fought over evolution (hardly squelched in the public mind or in many parts of the country and schools, regardless of recent court rulings) tell us anything about science literacy, it is that in the political arena, our national understanding of the nature of science is of critical importance to our scientific and technological competitiveness. It is clear to most practicing scientists, especially those in midcareer, that knowledge about the nature of science grows slowly, typically over the years, along with the help of failed experiments, 
good ideas that turn out to be logistical nightmares, nasty anonymous reviews, and the ever-present search for money. It's asking a lot, indeed quite a lot, of a high-school physics class or a large university's freshman biology course for nonmajors to convey a deep appreciation for and understanding of the nature of science. It is not too much to ask, however, that a hands-on experience at any level open up a student's mind to consideration of the fundamental nature of scientific inquiry. The serious question is whether, even in college, a science course lab designed to "work" in a two- or three-hour time block functions as a true hands-on experience. After all, labs that don't produce desired results- think data demonstrating that osmosis has occurred-reflect poorly on a teacher's performance and usually on end-of-the-semester evaluations. There is little doubt, however, that wading in a pond, collecting aquatic plants or invertebrates, trying to identify them, and subsequently designing a study to deter-

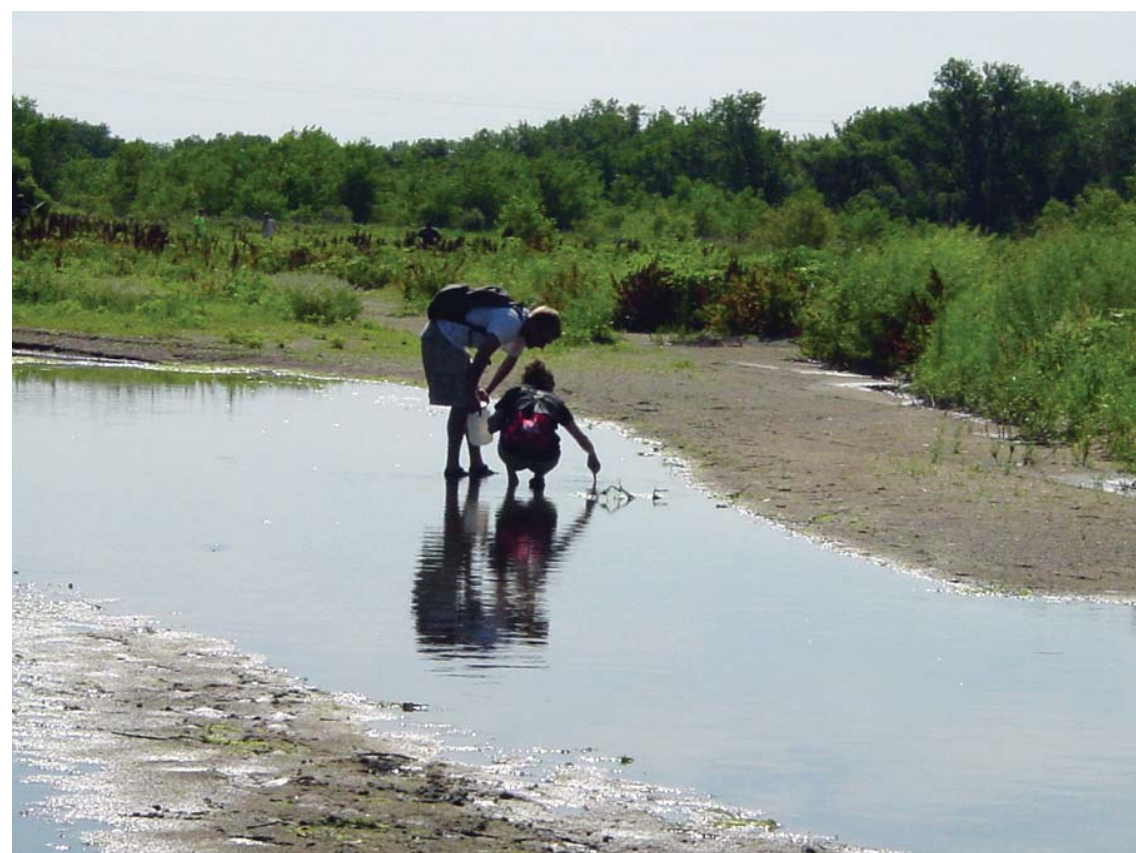

A decision in the river. Two students from the Cedar Point Biological Station decide on a project involving parasites of snails. Photograph: John Janovy Jr. mine the factors that regulate community diversity in that same pond do indeed teach one much about the nature of science, if for no other reason than that the next pond might be completely different biologically from the one you started on.

A relatively recent summary statement of the role that field programs can and do play in science education, along with some relevant numbers, can be found in the report of a workshop held in 2002, sponsored by the National Science Foundation (Klug et al. 2002). The authors are field station directors and active participants in the Organization of Biological Field Stations (www.obfs.org), a group with both individual and institutional members located predominantly in North America. The OBFS Web site lists more than 300 stations and ecological research centers, $60 \%$ to $70 \%$ of which offer both $\mathrm{K}-12$ and undergraduate instruction of various kinds, including formal courses and research opportunities. However, Klug and colleagues (2002) also identified a number of barriers to full utilization of existing facilities nationwide, including declining numbers of faculty members whose field experience or education is broad enough to qualify them to conduct field programs, a lack of formal recognition in merit and tenure decisions for teaching experience (not restricted to ecologists!), the costs of attending summer school, and insufficient coordination between field station courses and home institution curricula. Yet some programs remain healthy. At CPBS, both faculty reputation and home institution major requirements (e.g., general education credit for upperdivision courses) contribute to full classes, in some cases with waiting lists (e.g., BIOS 487/887, the unique field parasitology course in which we were doing the frog lung fluke exercise described above).
Residential field programs in general also tend to be characterized by two strangely polar yet connected aspects: first, a potentially life-changing and memorable encounter with the natural world, especially among college-age students for whom the elementary or middle-school field trip to a zoo, aquarium, or museum is but a distant and hazy memory; and second, a general lack of hard data to support or describe the first, especially to senior administrators and budget officers with no field program experience. Thus, most of what these programs accomplish is described anecdotally (see Klug et al. 2002), but there is virtually uniform agreement among scientists who have participated in such programs that, for students, the life-changing experience happens commonly, if not routinely. A minor manifestation of this phenomenon is the enrollment of field station students in city campus organismic biology courses, especially those that include regular field trips. Such enrollment often contradicts advice from prehealth professions advisers, who tell students things like "you don't need invertebrate zoology for premed" ("premed" is not really a major). We like to think that students who ignore such advice and take these kinds of courses anyway simply want more of what they got at the biological station.

Although again the evidence is anecdotal, faculty members who provide regular field trips in city campus courses such as ichthyology, invertebrate zoology, and botany contend that such trips can accomplish much the same thing as a field course. In our experience, this contention is relatively valid: in invertebrate zoology, for example, regular visits to local collecting sites cull a wealth of material that could never be ordered live from a supply house, and most important, much of that material allows observations on population 
structure and demographics. Even with only a three-hour block of time, if one has access to a relatively unkempt pond or stream, living aquatic insects and snails in many different developmental stages are often available. The idea that populations in general have structure is therefore encountered, not just presented in a lecture. This same kind of encounterbased learning can just as easily be done with plants, even in an untended urban vacant lot. While we're in the field, student behavior and conversation is almost identical to what we see and hear at the biological station. But at the end of lab, they leave, and once again modern life, most of it electronic and strident, intrudes.

From the perspective of a biological scientist trench soldier in a fairly large public university, American higher education seems to have evolved into a search for three seemingly essential items: (1) outside funding for research, with the attendant overhead delivered to a variety of accounts other than one's own; (2) publication in high-profile journals; and (3) some means of managing the throngs of young people who walk through our front doors every year. These people are mostly 18- to 24-year-olds, and they come to us with iPods plugged into their ears, cell phones beneath their ever-moving thumbs, laptops tuned to youtube.com via wireless networks supplied by the institution, and a lifetime's exposure to several thousand clamorous messages a day about athletic competition, fashion, sex, prescription drugs, peer relationships, religion, and money. On average, the majority of them are female (at our univeristy, about 1400 students a year, 60\% of whom are female, enroll in general biology), and in biological science classes, a large fraction also hope to enter a career in the health care industry, ranging from athletic training to physical therapy to neurosurgery.

The institution has a vested interest in keeping these young people in college, collecting their tuition for at least eight semesters, and then passing them on to their desired professional schools with grateful pride and a feeling of consumer satisfaction. In this kind of system, very few students will ever sit down with a faculty member for a one-on-one talk about writing, very few will visit a local art museum or read a serious nonfiction book that is not assigned for a class, and even fewer will choose to explore some arcane subject just to satisfy their curiosity. Most of them will struggle with time management, and much of what they will learn in their first two years is how to balance the demands of large classes, significant others, parental pressures, and a job. Yet all of them have only 4 or 5 years to be real college students, whereas they have 40 or 50 years to be something else.

If the ideals of higher education survive in this management-oriented, information technology-driven milieu, that survival is enabled by individual faculty members and programs that allow encounters with "real stuff," encourage if not require original work, promote reflection on one's own intellectual performance, and provide an opportunity to bring some defined endeavor to closure. In other words, these ideals are sustained by asking, or allowing, students to do what faculty members themselves do in order to sustain their expertise. To a biologist, real stuff is living organisms in their natural environments. Of all the facilities that colleges and universities provide, biological field stations are the ones in which these ideals and student behaviors are sustained and engaged in most easily.

Finally, we probably owe an apology to the honors student who instantly thought of the Internet as a tool for calculating the volume of the area in which frogs were getting infected with flukes. Those calculations can be done using data from Google Earth and are remarkably easy, although in the city campus building where we teach biology, there are no insect sounds, no smells of the prairie, no creaking windmills, no splashing, and no happy student conversations about aquatic insects.

\section{References cited}

Allen GE. 1978. Thomas Hunt Morgan: The Man and His Science. Princeton (NJ): Princeton University Press.

Bell RL, Blair LM, Crawford BA, Lederman NG. 2003. Just do it? Impact of a science apprenticeship program on high school students' understandings of the nature of science and science inquiry. Journal of Research in Science Teaching 40: 487-509.

Berger M. 1968. Famous Men of Modern Biology. New York: Thomas Y. Crowell.

Falk JH. 1983. Field trips: A look at environmental effects on learning. Journal of Biological Education 17: 137-142.

Freedman MP. 1997. Relationship among laboratory instruction, attitude toward science, and achievement in science knowledge. Journal of Research in Science Teaching 34: 343-357.

Klug MJ, Hodder J, Swain H. 2002. The Role of Biological Field Stations in Education and Recruiment into the Biological Sciences. (13 January 2009; www.obfs.org/ed/index.php?location=complete)

Knox KL, Moynihan JA, Markowitz DG. 2003. Evaluation of short-term impact of a high school summer science program on students' perceived knowledge and skills. Journal of Science Education and Technology 12: 471-478.

Markowitz DG. 2004. Evaluation of the long-term impact of a university high school summer science program on students' interest and perceived abilities in science. Journal of Science Education and Technology 13: 395-407.

Orion N, Hofstein A. 1994. Factors that influence learning during a scientific field trip in a natural environment. Journal of Research in Science Teaching 31: 1097-1119.

Ornstein A. 2006. The frequency of hands-on experimentation and student attitudes toward science: A statistically significant relation. Journal of Science Education and Technology 15: 285-297.

Wilson EO. 1994. Naturalist. Washington (DC): Island Press.

Zoldosova K, Prokop P. 2006. Education in the field influences children's ideas and interest toward science. Journal of Science Education and Technology 15: 304-313.

John Janovy Jr. (e-mail: jjanovy@unlserve.unl.edu) and Krista M. Major (e-mail: kmmajor@aol.com) arewith the School of Biological Sciences at the University of Nebraska-Lincoln. 